\title{
The Dynamics of the Constellation of East Asia: Japan's Response towards Changes of the Regional Status-quo Post-Panmunjom Declaration
}

\author{
Satwika Paramasatya ${ }^{1}$ \\ Department of International Relations ${ }^{1}$ \\ Universitas Diponegoro ${ }^{1}$ \\ sparamasatya@gmail.com ${ }^{1}$ \\ Yemima Galih Pradipta ${ }^{2}$ \\ Department of International Relations ${ }^{2}$ \\ Universitas Diponegoro ${ }^{2}$ \\ yemima.gp@gmail.com / yemimagp@students.undip.ac.id ${ }^{2}$
}

\begin{abstract}
ABSTRAK
Keamanan merupakan aspek penting bagi negara. Secara khusus, keamanan regional memainkan peran penting untuk memengaruhi kebijakan dan tindakan suatu negara. Makalah ini berangkat dari peristiwa pertemuan Tingkat Tinggi antara Korea Selatan dan Korea Utara pada April 2018 yang kemudian menghasilkan Deklarasi Panmunjom. Tetapi perjanjian damai tersebut ternyata berdampak lain bagi Jepang, karena menjadi turning point dari given situation atau status-quo yang selama ini ada di regional Asia Timur. Hubungan antar negara dalam regional ini umumnya lebih banyak didorong dan dimotivasi oleh kepentingan daripada kesamaan identitas. Tulisan ini bertujuan untuk menganalisis tindakan dan respon Jepang sebagai negara yang masih berstatus pasifis terhadap perubahan konstelasi hubungan Asia Timur pasca Deklarasi Panmunjom. Untuk dapat menjawab hal tersebut, penulis menggunakan teori realisme klasik untuk menganalisis tindakan Jepang. Pada akhir penelitian ini, penulis menyimpulkan bahwa apa yang terjadi di regional Asia Timur ini sesuai dengan konsep realisme klasik. Selain itu, Deklarasi Panmunjom memang merupakan peristiwa yang menandai adanya perubahan dalam status-quo regional Asia Timur, tetapi belum dapat menjadi faktor utama yang mendorong bagi Jepang untuk melakukan revisi konstitusi pasal 9. Namun kewaspadaan Jepang terhadap Korea Utara tetaplah sama. Sekalipun bukan faktor utama, tetapi Deklarasi Panmunjom membuat Jepang memaknai posisinya secara berbeda di Asia Timur, dan telah memengaruhi narasi Shinzo Abe untuk makin mengusahakan agar agenda revisi segera terealisasi.
\end{abstract}


Kata Kunci: Deklarasi Panmunjom, Semenanjung Korea, revisi konstitusi, Shinzo Abe, Asia Timur, keamanan, nuklir.

\section{ABSTRACT}

Security is important aspect for a state. In particular, regional security plays important role in influencing state policies and actions. This paper departs from the High-Level meeting between South Korea and North Korea in April 2018 which then produces an output in the form of the Panmunjom Declaration. But the declaration has different impact to Japan, because it becomes the turning point of the status-quo in the East Asia region. Relations between states are generally driven and motivated by interests rather than the shared identity. This paper aims to analyse the actions and responses of Japan as a pacifist state towards the changes in the constellation of East Asia relations after the Panmunjom Declaration. In the end of this paper, I conclude that what happened in the East Asia region is accordance to the concept of classical realism theory. The Panmunjom Declaration surely is an international event marked as turning point of East Asia regional status-quo, but cannot be claimed as the main factor to drive Japan revising article 9. However, Japan's alertness towards North Korea remains same. Even though it is not the main factor, but the Panmunjom Declaration made Japan interprets its position differently in East Asia, and has influenced Shinzo Abe's narrative to further strive for the revision agenda to be realized immediately.

Keywords: Panmunjom Declaration, Korea Peninsula, constitution revision, Shinzo Abe, East Asia, security, nuclear

\section{Introduction}

State and security are two inseparable things. The survival of a state depends on the stability and dynamics of its security, both domestically and internationally. Departing from this concept, it is not wrong to say that regional security plays important role for states. This paper will take East Asia as the main region to be discussed. Uniquely, the security within that region is difficult to implement collectively. Unlike Southeast Asia which then gave birth to ASEAN (Association of Southeast Asian Nations), the East Asia region does not have an integrated regional or multilateral organization. Relations between states in East Asia tend to be driven by interests. Over the past few decades, the constellation of regional relations in East Asia has been in a statusquo position where North Korea is considered as a joint threat due to its ownership of nuclear weapons. The threats centered on North Korea thus became an indirect 
binding for Japan, South Korea, and China. The three states oftenly threw critiques to North Korea, especially after North Korea conducted nuclear weapons trials.

But this constellation has changed since North Korea and South Korea decided to open up to each other and declare peace. Moon Jae-in (as the President of South Korea) met Kim Jong Un (as the Supreme Leader of North Korea) in April 2018, and it has marked a new chapter in the security constellation of the Korean Peninsula region. In the past, the Korean Peninsula was one of the 'battlefields' of the Cold War. The Korean war that occurred in 1950-1953 had ended with a ceasefire agreement signed by representatives of the United Nations, the Republic of China, and North Korea. The Republic of Korea (now South Korea) did not sign the agreement. This summit resulted in the Panmunjom Declaration which was later considered as a peace-making effort between the two parties and the Korean war conflict resolution effort. The content of the declaration is:

1. South and North Korea will reconnect the blood relations of the people and bring forward the future of co-prosperity and unification led by Koreans by facilitating comprehensive and groundbreaking advancement in inter-Korean relations. Improving and cultivating inter-Korean relations is the prevalent desire of the whole nation and the urgent calling of the times that cannot be held back any further.

2. South and North Korea will make joint efforts to alleviate the acute military tension and practically eliminate the danger of war on the Korean Peninsula.

3. South and North Korea will actively cooperate to establish a permanent and solid peace regime on the Korean Peninsula. Bringing an end to the current unnatural state of armistice and establishing a robust peace regime on the Korean Peninsula is a historical mission that must not be delayed any further (Ministry of Foreign Affair Republic of Korea, 2018).

A follow-up assembly took place on September $17^{\text {th }} 2018$, when Moon-Jae in and his wife headed to Pyongyang. Moon and Kim did sign an agreement to ease tensions at the border zone of militarization, as well as an agreement to each pull back 11 border guard posts at the end of the year (Denyer \& Kim, 2018). Although this appears promising for the security of the East Asia region, turns out that this has another impact for Japan. If beforehand North Korea had always become state which constantly criticized for its nuclear possession, this time North Korea had turned its global perspective on it. Japan's position as a pacifist state makes it difficult to get a role in the constellation of East Asia regional relations after the Panmunjom Declaration. Especially when North Korea has held a number of bilateral meetings with several other states, proving that it has finally opened up to the international talks. Among them was a meeting between Kim Jong Un and Donald Trump in 
Singapore in June 2018 as a follow up on the denuclearization commitment. Shortly after, Kim visited Beijing for two days to meet with President Xi Jinping to discuss the denuclearization of the Korean Peninsula in order to achieve true peace (CNBC, 2018).

The constellation of regional relations in East Asia has long been in the status-quo where North Korea has become a state that poses real pressure and threats because of its ownership of nuclear weapons, even conducted several nuclear bomb tests. In this pattern of relations, Japan still has an equal position with South Korea and China because the main source of threat is concentrated only in North Korea. After the Panmunjom Declaration, the pattern of relations changed and at some point, the regional security constellation actually pressed Japan. Its status as a pacifist country has forced Japan to rethink about how to not be left behind and lose its position in East Asia regional relations. In the other hand, the movement of other states in East Asia that is not so frontal also raises unexpected possibilities.

This paper intends to explain how Japan responded to the changing constellation of East Asian regional relations while still hold its pacifist state. It should be emphasized that this region is very dynamic and relations between the four states tend to fluctuate and commonly based on clear interests. This proves that the East Asia region is nonetheless in anarchy. In the condition of anarchy and the absence of strong cooperative relations, Japan ought to action to maintain its position in the regional constellation. Thus, this paper will be analyzed using classical realism theory to provide explanations about the possible actions Japan will take as a self-help motion in the constellation of regional relations in East Asia.

Classical realism is a theory which talk about two things, that is about the problem of the security of sovereign states in international anarchy and the issue of international order. The normative basis of realism is the survival of the state and national security (Jackson \& Sorensen, 2013, p. 168). Realism predicts that anarchy fosters hostile conditions in which countries must join in alliances, with or against one another to balance asymmetric forces. This main concept is known as balance of power. Hans. J. Morgenthau equated this concept of balance with equilibrium. When equilibrium is disturbed, either by external forces or by changes in one element or the other in a system, the system will show a tendency to rebuild from the original or create a new equilibrium. From there, the state as the main actor of international relations will make efforts to balance power. The balancing process can be done by reducing heavier scale weights or by adding lighter weights. The balancing methods include divide and rule, compensation, armaments, forming alliances, and maximizing the role of the holder or the balance of power (Morgenthau, 1948). Thomas Hobbes stated that the natural state of all humans is war. He stated that all individuals, as well as the state, had a natural equality, thus giving rise to the 
assumption: "the weakest have enough power to kill the strongest, either by secret means, or by confederation with others". If some are stronger than others, social order may be forced (Donnelly, 2004). Dynamic regional conditions and driven by interests are very appropriate when explained using classical realism. Especially when given situation in East Asia is in a position where state actors are balance and stable but in the context of conflict. Existing relationships between them are not driven by shared identity. In addition, the approach to be taken by Japan will be related to the development of the military so that the SDF has flexibility to do their roles, therefore, classical realism is the right theory to analyze the existing problems in this paper.

This paper will be divided into four parts. In order to effectively assess how Japan, as a pacifist state, will react and respond towards changes in the constellation of East Asia relations after the Panmunjom Declaration, this paper will first discuss the dynamics of the narration and the development of the revision of the Japanese constitution article 9 by Shinzo Abe. It is at the second part of this paper. As the current leader of Japan, he has an important role in building the urgency of revision in response to changes in regional conditions. Thus, this paper will combine Japan's internal conditions with the situation in the East Asia region. The third part of the paper take greater focus on the analysis and assessment of this event in the viewpoint of classical realism. A set list of indicators certainly included for understanding the issue according to some concepts in classical realism. From there, this paper will determine the extent to which Shinzo Abe as a leader is able to translate the Panmunjom Declaration as a threat and its relevance to Japan's position in East Asia thus it will affecting the urgency of self-help in the form of revision of the Japanese constitution article 9. Finally, the paper concludes the answers to the main questions raised about how Japan redefined its positions in the constellation of East Asia relations after Panmunjom Declaration, which was able to change the given situation existed since long ago.

\section{The Revision of Article 9 and the Impact of the Panmunjom Declaration}

\subsection{Progress of the Revision of Article 9}

Japan's status as a pacifist state is more or less stated in its constitution, precisely in article 9 chapter 2 which reads:

Aspiring sincerely to an international peace based on justice and order, the Japanese people forever renounce war as a sovereign right of the nation and the threat or use of force as means of settling international disputes.

In order to accomplish the aim of the preceding paragraph, land, sea, and air forces, as well as other war potential, will never be maintained. The right of belligerency of the state will not be recognized (Prime Minister of Japan and His Cabinet, 1946). 
The proposal regarding constitutional revision and amendment, especially in article 9, actually has long been emerged. However, this proposal has been massively discussed and endeavored since the reign of government as prime minister was held by Shinzo Abe. The Japanese Prime Minister and LDP (Liberal Democratic Party) leader delivered a speech during the LDP party leader election meeting at the party headquarters in Tokyo, Japan September $10^{\text {th }}, 2018$. Abe, who returned to office in December 2012 (after serving in 2006) promised to increase defense and revive the economy, and is widely expected to defeat his rival, former defense minister Shigeru Ishiba, in the September $20^{\text {th }}, 2018$ election for his Liberal Democratic Party leader. The literal meaning of article 9 of the constitution is to prohibit the maintenance of the armed forces but has been re-interpreted so that it allows the military to defend itself. That is why Japanese military is more properly called a self-defense force, which is then called the Self-Defense Force or SDF. Abe wants to add a reference to SDF to clarify their status. But even this has sparked debate among conservatives who view the US-drafted constitution as a reminder of the humiliating defeat in World War II and by critics concerned about expanding the role of the SDF abroad (Reuters, 2018).

During this revision effort, there are pros and cons faced by Abe. The main challenge Abe has to face is public opinion. There are at least three major newspapers that always do polls on the progress of the constitution revision on a regular basis every year, that is Asahi Shimbun, Yomiuri Shimbun and Nikkei Shimbun. Even though many in the showed disapproval, the dynamics varied every year. In 2018, community disapproval increased. Polls by liberal Asahi, conservative Yomiuri and business-oriented Nikkei revealed similar long-term trends. So, while political leaders might see the benefits of changing the constitution, the Japanese public is far more skeptical. 


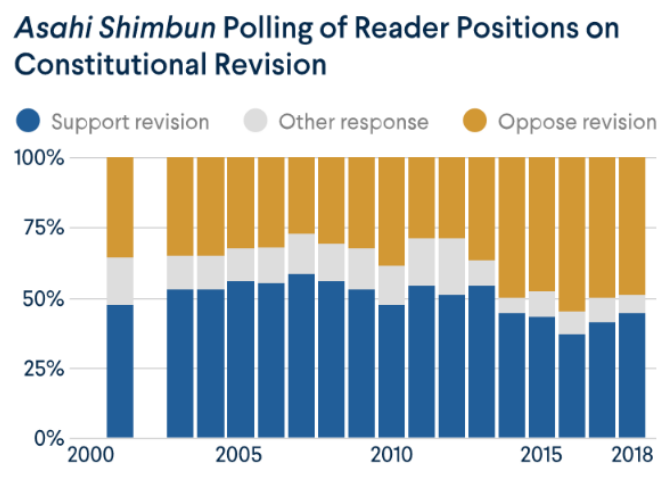

Note: Phrasing of questions differs by media outlet.

COUNCILon
FOREIGN FOREIGN

Diagram 1. Asahi Shimbun Polling of Reader Positions on Constitutional Revision (Council on Foreign Relations, n.d.)

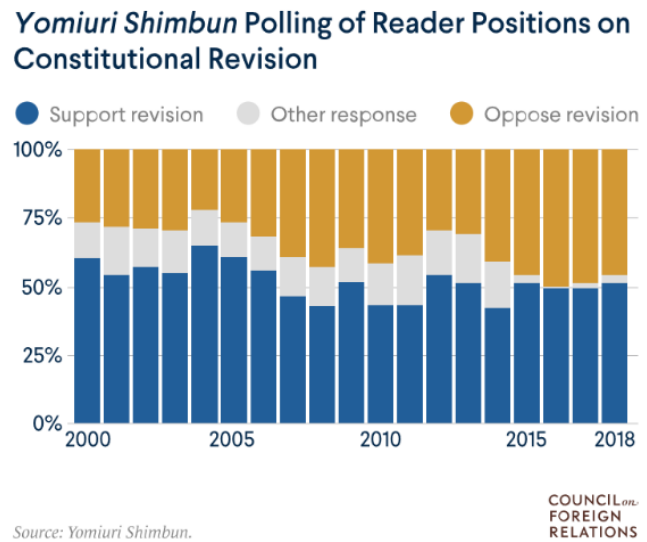

Diagram 2. Yomiuri Shimbun Polling of Reader Positions on Constitutional Revision (Council on Foreign Relations, n.d.)

Nikkei Shimbun Polling of Reader Positions on Constitutional Revision

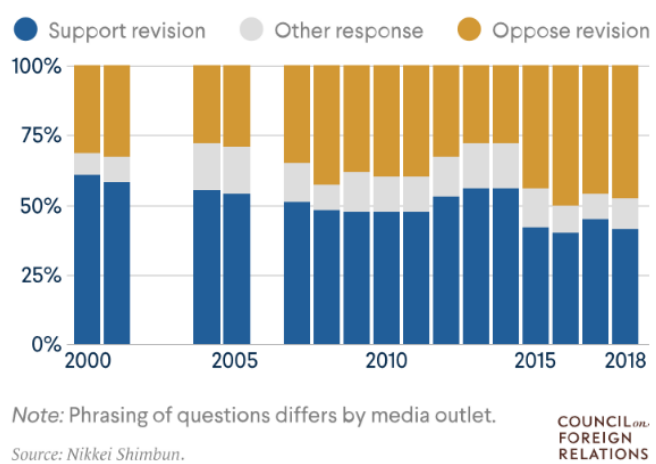

Diagram 3. Nikkei Shimbun Polling of Reader Positions on Constitutional Revision (Council on Foreign Relations, n.d.) 
Asahi Shimbun readers are typically quite wary of constitutional revisions, but their opposition has weakened over the past two years. By May 2018, the gap between those who opposed and those who agreed to the revision shrank to 5 percent, with 49 percent against and 44 percent supporting. Readers are mostly against changes to Article 9. The Yomiuri Shimbun itself tends to support the revision of the constitution, after offering its own revision proposals in 1994, 2000, and 2004. A small number of readers agree, according to the May 2018 poll. But in the Nikkei Shimbun poll, a Japanese business daily newspaper, shows that its readers are shaken in their support for revision. While more than 60 percent supported the revision in 2000, only 41 percent did so in 2018 (Council on Foreign Relations, n.d.).

Thus, in general, those are the average Japanese public shows disapproval of revising article 9 of the constitution. This is one of the many challenges that Abe must face to be able to revise the article 9 constitution. Significant decreases were found in 2018. But when talking about a state as a whole, it is also necessary to see the response of elites, government groups and parties. A quite different response was shown by parliament. Supports actually rise from the government and parties in parliament. In 2012, the Japanese Innovation Party (Ishin no Kai) joined the LDP as the second pro-revision party, and in 2017 the Party of Hope (Kibo no To) also declared itself a pro-revision party. The dynamics of the party gave the impression that the LDP could create a pro-revised coalition. Based on the data presented below, there has been a significant change in support for the LDP relating to advocating for constitutional revisions.

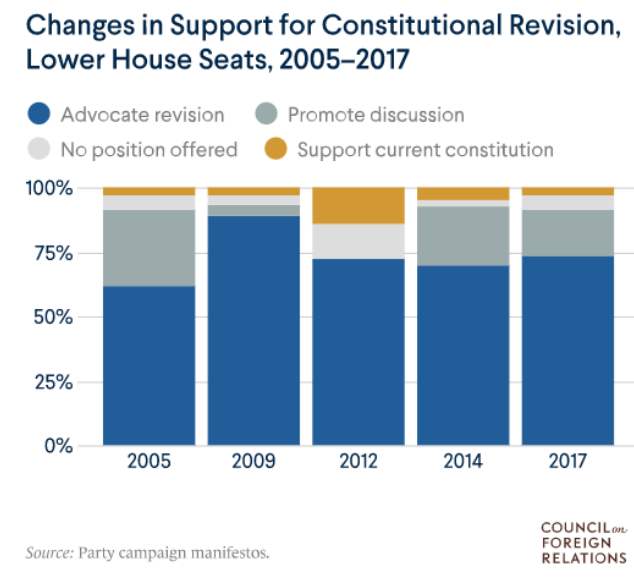

Diagram 4. Changes in Support for Constitutional Revision, Lower House Seats, 2005-2017 (Council on Foreign Relations, n.d.) 
The Japanese Constitution used to be understood as a law which prohibit international law's right of collective self-defense under all circumstances. Until a few years ago, the government's view had been that the Constitution's war-renouncing clause, Article 9, accepted solely the use of minimal necessary force to shield the territory and population of Japan-not other countries. So, for Japan to use force in collective self-defense (or even in cases licensed by the U.N. Security Council below Chapter VII of the U.N. Charter) would have been considered unconstitutional by means of the government due to the fact it would have exceeded this threshold. Japan could legally defend the population of a foreign country only if that population was in Japanese territory, such as American troops stationed in Japan. But this dramatically changed in 2014. Amid a lingering split in public opinion, Japan's Cabinet determined to carry the ban on collective self-defense, especially in a bid to "strengthen mutual cooperation with the United States." This used to be no longer executed by way of revising the Constitution-which has now not been amended in its 72-year historybut, instead, through reinterpreting its precept of minimum critical force, which continues to restriction the scope of Japan's permissible actions towards collective self-defense (Kurosaki, 2018). With smaller opposition parties open to providing their support, most pro-revision parties now enjoy a two-thirds majority in 242 upper house seats until 2019. This is coupled with a two-thirds majority in the ruling coalition in 475 seats in the Assembly Low (until 2018), it seems that the pro-revision side has been able to fulfill two of the three conditions or conditions to meet the revised constitution (the third requirement is support in a public referendum).

The LDP has been fighting for a revision of the 70-year-old constitution since the party was founded in 1955. Abe has advocated revisions throughout his career, and during the last parliamentary session, he repeatedly stated his desire to achieve revision while he was in office. In February 2019, the LDP held its annual party convention and Abe expressed his strong desire to revise Article 9 of the constitution, giving the JSDF full constitutional status (East Asia Forum, 2019). According to the latest poll, conducted by the Yomiuri Shimbun daily between August 24 and August 26, 45 percent of 1,076 respondents supported Abe's proposal to revise Article 9, while 38 percent opposed it. Seventeen percent refused to answer. The poll also showed that 31 percent thought the LDP should not send Abe's revised proposal to the Diet (parliament) at all. The results show that voters are sharply divided over all possible revisions in Article 9. To get more support from voters, Abe stressed that the revision was needed to end the long-standing academic debate about the constitutionality of the SDF, and that his proposal would not change any substance from current SDF military operations (The Japan Times, 2018).

Abe's attempt to revise the Article 9 constitution is not unreasonable. At least this is driven by external and internal conditions after World War II. At that time, Japan with its constitution, was known as a passive pacifist state, where Japan contributed to 
build world peace but in a passive context. Cooperation between the Japanese and the Allied forces worked relatively smooth. Criticism began to grow as the United States acted more and more in line with its interests in the Cold War, reintroduced resistance to communism, deployed more troops in Japan, and wanted Japan to build its own defense forces despite an article on anti-war in the Japanese constitution. With a peace treaty that came into force in 1952, the occupation of the United States ended. The Japan Self-Defense Force was established in 1954, accompanied by large public demonstrations. The great public unrest was also caused by the renewal of the 1960 US-Japan Security Agreement (Japan-Guide, n.d.). This situation has subsequently drawn criticism from the international community. Japan is deemed not to play a role commensurate with its international position and capabilities. Assistance provided by Japan mostly only in the form of financial assistance. Abe then proposed a concept or idea called "proactive contributions to peace", which then formally established in December 2013 in the National Security Strategy:

The key of national security is to create a stable and predictable international environment, and prevent the emergence of threats. It is thus necessary for Japan to realize an international order and security environment that are desirable for Japan, by playing an even more proactive role in achieving peace, stability and prosperity of the international community as a "Proactive Contributor to Peace" based on the principle of international cooperation.

His vision is clear: Japan's strategic intention is to proactively engage in international affairs. Abe's goal is to make Japan not only a consumer of security, but more of a security provider through its military power (The Diplomat, 2015).

After going through the 1990 s when Japan was criticized for relying only on "checkbook diplomacy," Abe acknowledged that the international community expected Japan to play a role in international affairs commensurate with its national capabilities and international position. Some years after Gulf War, Japan's global involvements have step by step evolved away from only financial or in-kind contributions towards greater proactive contributions to peace and security, though they had been by no means known as that. Whether it used to be anti-piracy operations in the Gulf of Aden, helping reconstruction efforts in Iraq, refueling coalition ships engaged in operations in Afghanistan, supplying humanitarian and disaster relief, or participating in UN-sanctioned peacekeeping operations, Japan has found non-financial ways to contribute to international affairs in ways commensurate with Japan's countrywide capabilities (The Diplomat, 2015). Another threat that Japan continues to watch out for is China's military strength which continues to increase, especially when Japan has had several disputes with China over several islands in the South China Sea. 
In addition to an external explanation, the effort to revise the constitution which is often echoed by Abe is also more or less influenced by the environment where he grows. Abe is a member of a prominent political family. His grandfather Kishi Nobusuke served as Japanese prime minister from 1957 to 1960, and his greatgrandfather Sato Eisaku held the same position from 1964 to 1972. Abe Shinzo was born on September $21^{\text {st }}, 1954$ as the son of Abe Shintaro, a journalist who a few years after Shinzo's birth began worked as secretary of the foreign minister, who happened to be his father-in-law, Kishi Nobusuke, and continued to work for him when Kishi became prime minister in 1957. When Abe Shintaro was appointed as chairman of the ruling Liberal Democratic General Council and later became party secretary general, his son continued to work for him as his personal secretary. Working with his father gave Abe insight and keen understanding of Japan's political performance, and when Abe Shintaro died in 1991, Abe Shinzo entered politics (Edstrom, 2007).

When entering a political career, Abe also wrote a book called Utsukushii kuni e [Towards a beautiful country], where Kishi emerged as Abe's hero. He wrote with admiration about his grandfather's actions and his political philosophy. The large impact on Abe's life made Abe must explain in detail who his grandfather was. In his book, Abe also wrote of his contempt for socialists, communists, and other left-wing forces that berated his grandfather and how conservatism was equated with the revival of militarism by intellectuals and the media. Having Kishi as his political hero has made Abe very aware of the defeat his grandfather encountered in the power struggle that occurred in Japan after World War II. One of the main commitments on Abe's personal political agenda was the promise to correct what was wrong for his grandfather by making post-war regime changes (Edstrom, 2007).

\subsection{Panmunjom Declaration in Nutshell}

April 2018 have marked an important period of historical transformation on the Korean Peninsula. This transformation brought the Korean Peninsula to a new era of peace in an effort to end the Civil War in 1950-1953. Moon Jae-in of the Republic of Korea and Kim Jong Un as Chair of the State Affairs Commission of the Democratic People's Republic of Korea held an Inter-Korean Summit in Panmunjom on April 27, 2018. Panmunjom is a village within the demilitarized zone. In front of 80 million Koreans, Moon Jae-in and Kim Jong-un declared to create a nuclear Peninsula region free of nuclear (denuclearization) and free from war both now and in the future, with the ideals of bringing the Korean Peninsula to peace, prosperity and reunification, which then summarized in Panmunjom Declaration (Reuters, 2018). 


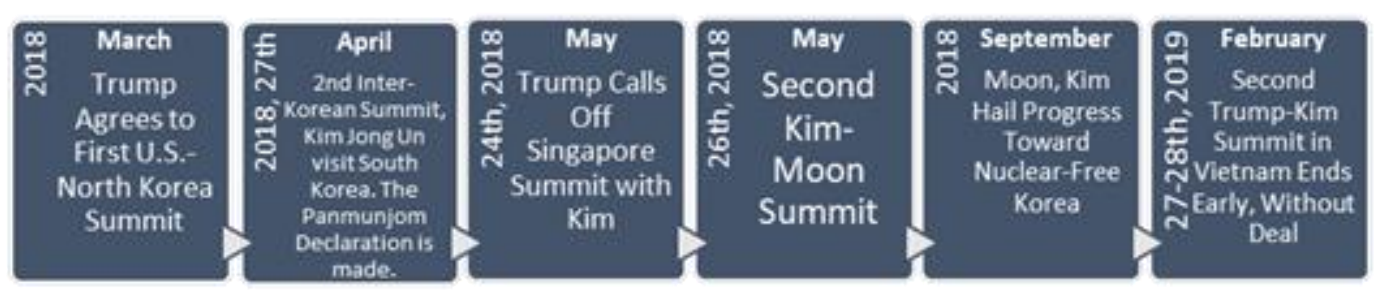

Chart 1. Chronology of the Change in the Constellation of Peace in North Korea (Council on Foreign Relations, n.d.)

There are four points emphasized in this agreement. First, the two states want to improve their relations as fellow countrymen and citizens in order to achieve independent prosperity and reunification. This improvement will be established through negotiations, dialogues, certain visits or cooperation carried out by all levels of society from both countries. This collaboration is also implemented with the modernization of the economy and infrastructure as a link between the two. In addition, as of August $15^{\text {th }}$, both parties agreed to hold separate family and relative reunions. Second, the two parties will make joint efforts to ease acute military tensions and to substantially eliminate the danger of war on the Korean peninsula. This objective is implemented by making efforts to stop offensive actions with each other in each regional domain, turning the North Boundary area in the West Sea into a maritime peace zone to prevent military clashes, and agreeing to hold frequent meetings between military authorities to discuss and resolve military problems that might arise in the future. And the third, the two countries are committed to building a permanent and stable peace regime on the Korean Peninsula. At this point, the two parties want to reaffirm the non-aggression agreement, and each will carry out a gradual disarmament to reduce military tension.

With this, Korea declared the end of the civil war. What needs to be highlighted from this point is that both will actively promote the holding of trilateral meetings involving the United States, or rectangular meetings involving the United States and China with the aim of replacing the Armistice Agreement with a peace treaty and building a solid peace regime. There are new rules of engagement to support these peace zones that apply to the two militaries. In addition, a number of previously agreed steps will also be implemented or reactivated, including: establishing a Joint North-South Military Committee, whose membership will be determined in accordance with the 1991 Basic Agreement; connecting high-level hotlines as agreed in the Joint Statement of 1974; disarming security guards in the Joint Security Areas; and allows joint use of the Han River Estuary, in accordance with the Armistice Agreement signed in 1953. Both parties will also withdraw a number of guard posts (Yoon, 2018). 


\section{The Analysis of Japan's Position in regional relations of East Asia After Panmunjom Declaration}

3.1. Panmunjom Declaration and the Revision of Article 9 in the View of Realism

This section specifically contains an in-depth explanation of the two phenomenas as part of the dynamic constellation of East Asia regional relations. But we need to look at the dynamics of regional relations in East Asia deeper and more focused by using classical realism theory as a tool to understand and analyze phenomena that occur. The first part will contain an analysis of actions and positions in Japan related to the revision of article 9 of the constitution and in the constellation of East Asian regional relations based on classical realism theory. The second part will focus on the relevance of the Panmunjom Declaration event with the revision of article 9 of the constitution, so that later it will lead to the answer to the formulation of the problem raised in this paper.

The main point of classical realism is state as the main actor acts to fulfill its interests. The phenomenon that occurs in the constellation of international relations will affect the pattern of relations of each country, and for realists, this pattern of relations tend to be driven by interest. Realism agrees that the anarchy situation that exists in the international world is the long-standing status quo, or in another word, given situation. That then allows the state to act in accordance with its own interests. Most of the state's behavior will have an impact on the given situation, so a term called security dilemma comes up. This dilemma arises because the power of states which has long been balanced, has become unbalanced because of a change. Morgenthau called this balance of power equilibrium. When equilibrium is disturbed, either by external forces or by changes in one element or the other in a system, the actors involved in the system will try to make an effort to balance the power, aka balance of power (Morgenthau, 1948). In practice, the form of balance of power varies. Specifically, in this study, Japan made a self-help effort to be able to balance power with military or armaments enhancements.

Set of indicators has been made to analyse the problems, that is:

1. State-centric. Keohane states that in world politics, the state is the main actor (Keohane, 1986, pp. 164-165). In this case, the state in question contains government elites and groups of people who contribute in making policies for state.

2. Anarchy. The international system is in anarchy (Mearsheimer, 1994), meaning that there is no higher government than the country itself. This is what drives the country to be in a natural situation where all state actors are in a balanced position, but also in the state of war. Hobbes called it a state in 
which the weakest have the power to kill the strongest, either by secret intrigue or by confederation with other actors (Hobbes, 1986).

3. Self-help and survival. No country can ensure that other countries will not use their military capabilities offensively against other state actors. Therefore, the most basic motive for the state to be able to continue is survival-or remain in the constellation of international relations (Mearsheimer, 1994). Self-help means that each state is responsible for its own survival and is free to determine its own interests and pursue power (Thucydides, 1972).

4. Security dilemma. Robert Jervis defines the security dilemma as a situation in which the way a country uses to increase its security turns out to reduce the security of the surrounding countries (Jervis, 1978).

5. Balance of power. In addition to seeing that the world is anarchy, realists also view security as a central problem. To achieve security, states try to increase their power and make a balance of power for the purpose of blocking the potential of aggressors (Thucydides, 1972, p. 23)The state must always pay attention to its relative strength. The power of other countries - especially large powers - is always interpreted as a threat. Weak countries may have no alternative but to guess correctly. They will "balance" against forces that grow from other countries (Donnelly, 2000).

The second part of this paper states that the attempt to revise the Japanese constitution article 9 has become an important agenda for the government under the leadership of Shinzo Abe. In realism, the state is the main actor in the constellation of international relations as well as in government policy making. Even though the conflict is in the community (common citizen), it is not the same with the government elite and LDP support party ranks. So in terms of realism, efforts to revise the Article 9 constitution have become Japan's national interest.

Looking at the constellation of East Asia regional relations, it can be seen that this region is in anarchy, because there are no organizations or institutions that have more authority than the state itself. The relations between them-especially South Korea, North Korea and Japan-cannot be categorized as harmonious. This is much influenced by the dark history of the past, where Japan committed many humanitarian crimes against North and South Korea. Distrust and suspicion of each other in the constellation of East Asian regional relations was manifested by the absence of integrated organizations to unite the four states in East Asia. Japan is actively inviting South Korea and other states to condemn North Korea. This surely natural, because Japan and South Korea are both countries that do not have a strong military and are dependent on the United States. The position of all actors is balanced, there is no absolute and significant binding because their relationship is 
only based on interests. But on the other hand, it is North Korea's position which is the main subject of the threat which then becomes an indirect bond between actors.

All of that is a given situation in East Asia. The condition that has existed for a long time has become a status quo that affects patterns of state relations in East Asia. All actors in East Asia are in equal position. After the Panmunjom Declaration, the constellation of relations changed and the status quo in East Asia collapsed. In realism, the state can only rely on itself, and this is caused by suspicion of one another. Therefore, in response to these conditions, Japan implemented self-help in the form of an effort to revise the Article 9 constitution. This revision would later enable Japan to have a strong military and could actively contribute to maintaining Japanese security. This must be done by Japan to some extent also influenced by changes in US relations with North Korea. Japan can no longer rely entirely on the US; he needs to equip himself with a strong and capable military.

After the event of Panmunjom Declaration, change in power occurs. They are previously balanced but then become unbalanced because the two Koreas decided to make peace and work together. In the viewpoint of realism, the change in statusquo which then leads to a security dilemma because power is no longer balanced between states. The revision of article 9 of the Japanese constitution as a form of self-help Japan aims to maintain Japan position in the constellation of East Asian regional relations. The power that was previously balanced because each state actor in East Asia relies on himself has changed, then has an impact on Japan's position. Japan can no longer invite South Korea to denounce North Korea and position North Korea as a common threat because the source of the threat has been to make peace with other actors in East Asia. Through this agreement, it can be interpreted that the two Koreas agreed to unite and combine their power to create peace with their respective interests. This seems promising for the security of the East Asia regional region, where in realism, this strategy is also part of the self-help of the two Koreas to survive in the regional security constellation. But from the standpoint of realism, these two united forces have damaged or changed the status-quo order of the East Asia regional power. For Japan, this is a serious threat because the source of threats that have been concentrated in North Korea has changed and is no longer relevant

The uncertainty also came from South Korea, which had opened itself to be friends with North Korea. It is difficult for Japan to return the direction of view of East Asia states to North Korea and put it at the center of the threat. On the other hand, the strength of China cannot be doubted, so that the country has enough 'ammunition' to survive in the East Asia regional constellation without having to cooperate specifically with Japan. Its power was even recognized by the Pentagon, through its official statement on January 15, 2019. The US Defense Intelligence Agency's open report said Beijing had made a huge military jump in recent years. The report said 
military advances included the capabilities of its newest capabilities in air, sea, space and cyberspace (Tempo.co, 2018). Japanese decision makers also know that China's military superiority in East Asia is increasing day by day and that Beijing is designing special weapons to counter traditional American domination in the region (Carpenter, 2019). At the same time, Tokyo can no longer fully depend on Washington under the leadership of Donald Trump, whose international policy is often unpredictable.

\subsection{Panmunjom Declaration and its Relevance to Japan Revision Agenda}

There are some basic things that need to be considered first to make us able to see the relevance of the Panmunjom Declaration event to the revision of the Japanese constitution article 9. The first is how Shinzo Abe, as a representative of the LDP - or in this context, representatives of the government elite, has succeeded in bringing up the narrative that the attempt to revise article 9 of the constitution is important and deserves consideration. Secondly, Abe has an important role in building the narrative that reunification and peace on the Korean Peninsula is a threat that needs to be watched out, so it then becomes a bridge for him to carry out public persuasion regarding the revision of article 9. This interpretation is important, because it leads to an understanding of Japan's position in the constellation of East Asia regional relations. Certainly, the Japan's position will encourage Japan to carry out certain strategies so that it can fulfill the aspects of self-help as explained in the previous section.

The Panmunjom Declaration made it difficult for Japan to get an East Asia geopolitical stage. As the only state that was attacked with a nuclear bomb, Japan played an important role in convincing one of its neighbors to stop its weapons program. Despite Abe's apparent enthusiasm, it is clear that his role in the region has been defeated by Moon Jae-in, the president of South Korea and his opposing ideological opponents. Moon, who has taken over the main stage in a geopolitical drama that has been watched all over the world, has exacerbated the loss of Abe's face. In addition, the Japanese effort to hold a meeting with North Korea was difficult to realize because there was not much that Japan could offer North Korea, nor could it present a credible military threat to force Kim to the negotiating table (Ryall, 2018).

For Japan, North Korea is a source of threat which Japan mostly alert about. This vigilance has actually appeared since before the Panmunjom Declaration because Japan had experienced a missile attack by North Korea. But this recessive position then arose precisely because North Korea did not appear to have provided significant progress towards denuclearization efforts on the Korean Peninsula. Leaders from South Korea, Japan and China on Wednesday, May 9th, 2018 gave a certain statement in support of the Panmunjom Declaration. The special statement was made after a trilateral meeting in Tokyo between President Moon Jae-in, Prime Minister Shinzo Abe and Prime Minister Li Keqiang from China. Meanwhile at the Moon-Abe 
talks, Japan has made it clear that sanctions imposed on the North should not be lifted unless Pyongyang demonstrates concrete denuclearization measures, emphasizing that the closing down of a nuclear testing site and a halt in the firing of ballistic missiles were not sufficient for sanctions relief. Abe said during the bilateral summit talk with Moon in the afternoon.that the most important is the timing when it comes to easing or withdrawing sanctions altogether on North Korea. Abe empashized the idea of not having to reward North Korea over their efforts to shut down the Punggye-ri nuclear site or stopping the test-firing of intercontinental ballistic missiles, and that the region actors need additional and substantive actions from the North (Jin-Kyu, 2018).

Meanwhile, Abe's attitude towards Kim was even more vigilant. The Japanese government plans to maintain its policy of pressuring North Korea despite expressing a degree of approval of the Panmunjom Declaration. This is because the government does not regard the Panmunjom Declaration as a tangible step towards the complete abandonment of North Korea's nuclear weapons and missiles. The government also plans to promptly gather information from South Korea about why the declaration and the joint press conference by the two leaders failed to mention the issue of abductions of Japanese nationals by North Korea (Straits Times, 2018). Japan vigilance is also seen in the annual white paper released by the Japanese Ministry of Defense. The document contains three states which Japan assumed as potential threats, that is China, North Korea and Russia. Given the maturity of the technology obtained through a series of nuclear tests, Japan assesses that North Korea has succeeded in making miniature nuclear weapons to match ballistic missile warheads. Although North Korea declared its intention to carry out full denuclearization on the Korean Peninsula and blow it up on its nuclear test site in public, North Korea has not dismantled all weapons of mass destruction and ballistic missiles from all ranks in a complete, verifiable and irreversible manner. Therefore, Japan drew the conclusion that there were no significant changes in North Korea's nuclear and missile capabilities (Japan Ministry of Defense, 2018).

The threat from the Korean Peninsula can be interpreted with a simple picture. Japan, with its pacifist status, is facing two countries that are at peace with one another, working together and complementing each other. When South Korea is progressing economically, socially and culturally, but is weak in the military, then it joins with North Korea which has a strong military; then both can emerge as a combination of new forces in the East Asian region. South Korea is ranked 7th among 43 countries in the Asia-Pacific region, and its overall score is above the regional and world average (Heritage, 2019).

In the Panmunjom Declaration agreement, it was stated that both of them were heading for the reunification process, and even had a North-South Joint Military 
Committee. This is what was captured by Shinzo Abe as a new threat. So far, Japan has a pretty good hegemony in terms of economy and culture, especially after the Visit Japan program or agenda which is very effective in increasing the attractiveness of tourism through culture. In fact, South Korean culture also has its own reputation throughout the world, especially among young people. Thus, the North and South become the right combination and complementary. Economically, North Korea will be greatly helped by South Korea and the socio-cultural movement of South Korea can also be more easily entered into North Korean society. On the other hand, South Korea has additional military power alongside the US, and of course, is more reliable because the existing ties with North Korea are based on the same brotherhood and identity. There is a possibility that this reunification will be dominated by North Korea due to North Korea's more favorable bargaining position.

Therefore, Japan should seriously consider this new power arises in East Asia. Coupled with the difficulty for Japan to hold bilateral meetings with North Korea, while Japan still has unfinished problems with North Korea related to the abduction of 13 Japanese citizens by North Korea. While the change in the status-quo apparently has little impact on China, because its military strength has proven to be strong and capable, so it can still be able to play an important role in the constellation of East Asian regional relations. In response for this, Japan has launched a defense policy which, over the next five years, will increase its security while maintaining its alliance with the United States. Ultimately, Japanese military leaders believed that the plan would overcome its regional problems while also allowing the country to assert its independence. Japan's five-year defense policy, issued in December 2018 and adopted four months later, calls for an integrated command structure that includes not only traditional military branches (such as the army, navy and air) but also appropriate defense capabilities for 21st century war, such as air space, cyber, electromagnetic units and even artificial intelligence that will operate under the integrated command of peace and war. In the end, Tokyo bet its safety on a hightech military that will make up for the shrinking domestic population (Carpenter, 2019).

The events of the Panmunjom Declaration have influenced Japan to be even more hasty in revising its pacifist constitution. This independent line also extends into defense policy: Japan has conducted military exercises abroad - a first step towards liberation from pacifist restraints of the constitution. Calls for revision of article 9 have also increased; society is no longer as pious as before. If implemented, such a revision would give Tokyo a greater choice to flex its military muscle and move forward with a stronger militarization policy. Tokyo has laid the foundation for an independent defense policy, as evidenced by its commitment to intelligent, rigorous high-tech military, and the development of military industrial complexes (Carpenter, 2019). 


\section{Conclusion}

Based on the data and analysis that have been presented, there are some conclusions to be explained in this paper. First, the authors agree that the constellation of regional relations in East Asia is unique. Its uniqueness lies in the pattern of relationships that are only based on interests. The background and history of the past makes it difficult for each actor to have a relationship that is purely based on shared identity or a spirit of cooperation that is free of interest. Then this then becomes the long-standing status-quo.

Second, the writer places North Korea at the center of the threat. Both Japan, South Korea and China are in a balanced position, with the central threat being in North Korea because of its ownership of nuclear weapons. Japan, in this case, can confidently do what is in its interests, even if it does not have a strong and offensive military to be able to control the East Asian region.

Third, the Panmunjom Declaration is indeed an event that marks a change in the East Asian regional status-quo, but it is not a major factor that encourages Japan to revise the constitution of article 9. It is more correct to say that the Panmunjom Declaration has influenced-rather than boosted-for Japan to interpret its position in the constellation of East Asian regional relations. If the two Koreas really do reunification, then they can emerge as a new power in East Asia that is even on a par with China, which is economically, socially, culturally and especially, militarily strong. But on the other hand, it is still too early for Japan to consider the Panmunjom Declaration as something that would seriously threaten its security. North Korea has long been considered a threat even before the Panmunjom Declaration. Meanwhile, Japan itself does not even consider South Korea a significant threat even though South Korea is also an actor involved in the agreement. This is evident in the annual white paper released by the Japanese government which only lists North Korea, China and Russia as state actors that need to be watched because it can bring regional instability, without including South Korea at all. Therefore, Japan's position of being pushed and threatened is more influenced by North Korea and China.

Fourth, even though the Panmunjom Declaration was not an event that could threaten Japan's pacifist status, it did affect how Shinzo Abe delivered the narrative about revision of article 9 of the constitution and its efforts to make the SDF have a more comprehensive role. This regional condition in East Asia was shifted because of the Panmunjom Declaration, which made Abe feel the need to accelerate the revision of the constitution. Abe's narrative became easier to convey when he and his cabinet still considered North Korea as a threat, especially since North Korea had not yet demonstrated tangible efforts to denuclearize. In the end, the regional status quo does not strongly show a total different change, but Shinzo Abe has already felt the 
threat of changing the given situation. Japan response in fact, quite simply, is unmoved and still remains wary of North Korea and China; not truly doing a major response to regional as a sign of being threatened.

Fifth, the attempt to revise the Article 9 constitution which is increasingly massive delivered by Shinzo Abe is indeed a form of self-help carried out by Japan so that it can survive in the constellation of East Asian regional relations. The product of this self-help is also reflected in the purchase of more advanced and modern military equipment by Japan to equip its military so that it can be more powerful. The effort for the military to become independent is also another proof of Japan's form of selfhelp to begin to abandon its pacifist status. Reflecting on the Panmunjom Declaration, Japan saw that the situation in the East Asian region became unpredictable, especially since the uncertainty came from the country that was the most closed and most threatening for Japan, that is North Korea. Another threat that Japan must face is the modernization of the Chinese military. With the US which may not always be a reliable ally especially with regard to security, Japan needs to take more independent steps regarding its military and defense.

\section{References}

Books

Donnelly, J. (2000). Realism and International Relations. Cambridge: Cambridge University Press.

Hobbes, T. (Ed). (1986). Leviathan intro. C. B. Macpershon. Harmonsworth: Penguin Books.

Keohane, R. O. (Ed.). (1986). Neoralism and Its Critics. New York: Columbia University Press

Morgenthau, H. J. (1 $1^{\text {st }}$ Ed) (1948). Politics Among Nations: The Struggle for Power and Peace. New York: Knopf.

Thucydides. (1972). History of the Peloponnesian War. trans. Rex Warner. Harmondsworth: Penguin Books. 
$\underline{\text { Journal Articles }}$

Edstrom, B. (2007). The Success of a Successor: Abe Shinzo and Japan's Foreign Policy. Washington DC, Massachussets, United States of America: Central AsiaCaucasus Institute \& Silk Road Studies.

Jervis, R. (1978). Cooperation Under the Security Dilemma. World Politics (30) 2, 167-214. Retrieved from http://www.jstor.org/stable/2009958.

Mearsheimer, J. (1994). The False Promise of International Institutions. International Security, 19(3), 5-49. doi: 10.2307/2539078. The MIT Press.

\section{$\underline{\text { Reports }}$}

Japan Ministry of Defense. (2018, December). Defense of Japan (Annual White Paper) (Report Year 2018). Retrieved June 27, 2019, from Japan Ministry of Defense: https://www.mod.go.jp/e/publ/w paper/pdf/2018/DOJ2018 Digest 1204.pdf

Japan Ministry of Defense. (2018, December 18). National Defense Program Guidelines FY 2019 and beyond. Retrieved July 31, 2019, from: https://www.mod.go.jp/j/approach/agenda/guideline/2019/pdf/20181218 e.pdf

Prime Minister of Japan and His Cabinet. (1946). The Constitution of Japan. Retrieved September 19, 2018, from: https://japan.kantei.go.jp/constitution and government of japan/constitution e.h tml

Ministry of Foreign Affair Republic of Korea. (2018, April 27). Panmunjom Declaration for Peace, Prosperity and Unification of the Korean Peninsula. Retrieved from http://www.mofa.go.kr/eng/brd/m 5478/view.do?seq=319130\&srchFr=\&amp; srch To=\&amp;srchWord=\&amp;srchTp=\&amp;multi itm seq=0\&amp;itm seq $1=0 \& a$

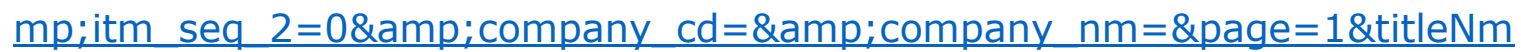

\section{Internet Sources}

Carpenter, E. M. (2019, June 3). Japan's High-Tech Militarization: Asserting Independence in an Uncertain World. Retrieved June 14, 2019, from Stratfor Contributor Perspectives: https://worldview.stratfor.com/article/japans-high-techmilitarization-asserting-independence-uncertain-world

CNBC. (2018, June 19). Kim Jong Un and China's Xi discuss 'a new future,' North Korean media says. Retrieved Desember 6, 2018, from CNBC: https://www.cnbc.com/2018/06/19/north-koreas-kim-jong-un-in-china.html 
Council on Foreign Relations. (n.d.). North Korean Nuclear Negotiations 1985-2019. Retrieved May 28, 2019, from https://www.cfr.org/timeline/north-korean-nuclearnegotiations

Council on Foreign Relations. (n.d.). Public Attitudes on Revision. Retrieved May 14, 2019, from Constitutional Change in Japan: https://www.cfr.org/interactive/japanconstitution/public-attitudes-on-revision/

Denyer, S., \& Kim, M. J. (2018). Kim pledges to visit Seoul, a first for a North Korean leader, but he and Moon give few details on denuclearization. Retrieved September 20, 2018, from The Washington https://www.washingtonpost.com/world/south-koreas-moon-travels-to-pyongyangin-bid-to-revive-stalled-nuclear-talks/2018/09/17/d5b401fa-ba5c-11e8-b1c57a2126bc722c story.html?utm term $=.3 a 88 d 5 c 4 e 882$

East Asia Forum. (2019, March 28). Is constitutional revision a bridge too far for Abe? Retrieved April 24, 2019, from https://www.eastasiaforum.org/2019/03/28/isconstitutional-revision-a-bridge-too-far-for-abe/

Heritage. (2019). 2019 Index of Economy Freddom: South Korea. Retrieved September 23, 2019, from https://www. heritage.org/index/country/southkorea

Japan-Guide. (n.d.). Post War History (since 1945). Retrieved May 1, 2019, from https://www.japan-guide.com/e/e2124.html

Jin-Kyu, K. (2018, May 10). Moon, Li, Abe affirm Panmunjom Declaration. Retrieved June 27, 2019, from http://koreajoongangdaily.joins.com/news/article/article.aspx?aid=3047935

Kurosaki, M. (2018, August 23). Japan's Evolving Position on the Use of Force in Collective Self-Defense. Retrieved May 15, 2019, from Lawfare: https://www.lawfareblog.com/japans-evolving-position-use-force-collective-selfdefense

Reuters. (2018, September 10). Japan's Abe aims for constitution change in bid for extended term. Retrieved April 24, 2019, from https://www.reuters.com/article/usjapan-politics/japans-abe-aims-for-constitution-change-in-bid-for-extended-termidUSKCN1LQOAU

Reuters. (2018, April 28). Panmunjom Declaration for Peace, Prosperity and Unification of the Korean Peninsula. Retrieved March 25, 2019, from Reuters: https://uk.reuters.com/article/uk-northkorea-southkorea-summitstatemen/panmunjom-declaration-for-peace-prosperity-and-unification-of-thekorean-peninsula-idUKKBN1HY193 
Ryall, J. (2018, March 18). Abe's nuclear disaster: why has Japan been shut out of North Korea talks? Retrieved June 27, 2019, from https://www.scmp.com/weekasia/geopolitics/article/2137382/abes-nuclear-disaster-why-has-japan-been-shutout-north-korea

Straits Times. (2018). North Korean leader Kim Jong Un ready to talk with JapanSeoul. Retrieved October 10, 2019, from https://www.straitstimes.com/asia/eastasia/north-korean-leader-kim-jong-un-ready-to-talk-with-japan-south-korea

Tempo.co. (2018). Fakta Senjata Cina yang Diakui Pentagon Paling Maju di Dunia. Retrieved June 14, 2019, from https://video.tempo.co/read/13184/fakta-senjatacina-yang-diakui-pentagon-paling-maju-di-dunia

The Diplomat. (2015, October 27). Gauging Japan's 'Proactive Contributions to Peace'. Retrieved May 1, 2019, from https://thediplomat.com/2015/10/gaugingjapans-proactive-contributions-to-peace/

The Japan Times. (2018, September 20). Constitutional revision, fraught with risk, tops agenda for Abe's next term. Retrieved April 25, 2019, from https://www.japantimes.co.jp/news/2018/09/20/national/politics-

diplomacy/constitutional-revision-fraught-risk-tops-agenda-abes-nextterm/\#.XMERC-gzbIU

Yoon, S. (2018, October 2). North and South Korea's New Military Agreement. Retrieved May 29, 2019, from https://thediplomat.com/2018/10/north-and-southkoreas-new-military-agreement/ 